\title{
The Effects of Dadih Supplementation on Duration of Acute Diarrhea, Secretory Immunoglobulin A Level, and Tumor Necroting Factor Alfa Level in Mice Induced with Enteropathogenic Escherichia Coli
}

\author{
Yusri Dianne Jurnalis ${ }^{1}$, Eryati Darwin ${ }^{2}$, Yanwirasti ${ }^{3}$, Nasrul Zubir ${ }^{4}$ \\ \{yusridianne12@gmail.com ${ }^{1}$, eryatidarwin@fk.unand.ac.id ${ }^{2}$, yannwirasti@yahoo.com ${ }^{3}$, \\ nasrulzubir@yahoo.com ${ }^{4}$ \} \\ Pediatric Department, Faculty of Medicine Andalas University, Padang, Indonesia ${ }^{1}$ \\ Histology Department, Faculty of Medicine Andalas University, Padang, Indonesia ${ }^{2}$ \\ Anatomy Department, Faculty of Medicine Andalas University, Padang, Indonesia ${ }^{3}$ \\ Internal Medicine Department, Faculty of Medicine Andalas University, Padang, Indonesia ${ }^{4}$
}

\begin{abstract}
Diarrhea is the second leading cause of death among children under five years old. There is a new paradigm that probiotic can be used as a supplement to treat diarrhea. Probiotic consists of lactic acid bacteria (LAB) that induce the immunity and increase absorption process in intestinal villi. In West Sumatera, there is traditional probiotic known as dadih made from fermented buffalo milk. In this study we aim to assess the effects of dadih supplementation on acute diarrhea duration, secretory immunoglobulin A and tumor necroting factor (TNF) alpha level in mice induced with enteropathogenic Escherichia coli (EPEC).In this experimental, analytical study, we used 30 mice induced with EPEC, divided into negative control group, positive control group induced with EPEC, and treatment group induced with EPEC and was given $112 \mathrm{mg}$ dadih $/ 20 \mathrm{gr}$ BW daily for 14 days. Statistical analysis was performed using one way ANOVA, Kruskal Wallis and post hoc LSD. The result showed a mean of diarrhea duration was shorter in the treatment group $(4.10 \pm 1.52, \mathrm{p}=0.000)$. The mean of TNF- $\alpha$ level was lower in the treatment group $(173.18$ $\pm 70.48 \mathrm{p}=0.055)$, and mean $\operatorname{sIgA}$ level was higher in the treatment group $(8.69 \pm 2.43$, $\mathrm{p}=0.208$ ). Dadih administration shortened the duration of acute diarrhea, but did not show any statistically significant effects in the reduction of TNF- $\alpha$, and increasing of SIgA level. The study showed that administration of dadih did not significantly affect sIgAand TNF$\alpha$ levels in mice given EPEC.
\end{abstract}

Keywords: Dadih, Diarrhea Duration, Mice, Secretory Immunoglobulin A, Tumor Necroting Factor Alfa.

\section{Introduction}

Diarrhea is the second leading cause of death among children under five years old, where every year 760,000 died of diarrhea[1]. One of the underlying cause is enteropathogenic Escherichia coli (EPEC) that adheres in the intestinal mucosa, causes changes in epithelial cell structure, and invades inner mucosal cell resulting in infection and diarrhea[2].

There is a new paradigm in manipulating the existence of probiotic microorganism that lives in the intestine. Probiotic is defined as a living microorganism. If it consumed in adequate 
level will bring benefit for the host[3] Probiotic plays the role to keep micro-ecosystem so that it will prevent pathogenic colonization that can cause diarrhea or other diseases, and trigger the mucosal immune response to produce immunoglobulin A (IgA) as local humoral immunity of intestinal mucosa and mucosal cell-mediated immunity (CMI)[4]. The supplemented probiotic can protect epithelial cells from destruction by Escherichia coli and protect mucosa from destruction by TNF- $\alpha[5]$.

In West Sumatera, a traditional probiotic is known as dadih. Dadih is traditional food made from fermented buffalo milk containingprobiotic[6]. Dadih fermentation occurs in a bamboo container in room temperature for 24-28 hours. This means that the fermentation occurs naturally without requiring a starter substance. Pato argues that dadih's microorganism came from banana leaf used as the lid, bamboo container and the buffalo milk itself[7].

Recent studies about the role of lactic acid only focus on commercial probiotic isolate or dadih isolate, while this study focuses on using whole dadih as the probiotic in the therapy of acute diarrhea. The novelty of this study is using dadih as supplemental therapy for acute diarrhea in children.

The product from the isolation of lactic acid bacteria (LAB) in dadih has 36 Lactobacillus strains, Streptococcus[7,8] and Lactococcus[6,9]. Other than that, non LAB bacteria were also found such as Micrococcus variants, Bacillus cereus, Staphylococcus saprspontaniousophyticus and Endomyces lactis[9]. Bacteria in buffalo milk consists of Gram-positive bacteria $73.7 \%$ and Gram-negative bacteria 26.3\% [10]. The study aims to assess the effects of dadih supplementation on acute diarrhea duration, secretory Immunoglobulin A level, and Tumor Necroting Factor alfa level in mice induced with enteropathogenic Escherichia coli.

\section{Materials and Methods}

An experimental, analytical study with randomized posttest-only controls group design. Criteria for inclusion were male, white mice (Mus musculus) from animal development unit of Pharmacology Laboratory of Andalas University, 6-8 weeks of age, 20-30 gram of weights, healthy without any deformities. Criteria for exclusion were sick or dead mice before 14 days in the study. The sample size calculation was based on the Federer formula for sample size determination in experimental animal studies. Minimum sample size calculated for this study was 30 mice or 10 mice per group (after considering a $10 \%$ dropout rate). The sample was selected randomly.

In this study dadih is defined as traditional food made from fermented buffalo milk containing lactic acid bacteria as probiotic, occurs naturally without requiring a starter substance in a bamboo container in room temperature for 24-28 hours[11]. Acute diarrhea is when the mice have defecation frequency more than 12 times/day with feces consistency turning into half liquid or liquid for less than 14 days[12]. Duration of diarrhea is the beginning of diarrhea after treatment until feces consistency becomes normal and/or frequency of defecation less than 12 times/day [12]. We define sIgA as the level of the main immunoglobulin found in mucous, with molecular weight 165,000 daltons contained in feces of infected mice and given dadih[13]. TNF- $\alpha$ is the main cytokine and strong mediator which response to acute inflammation due to gram-negative bacteria producing lipopolysaccharide (LPS) in infected mice feces and given dadih [13].

Dadih was obtained from Bukittinggi, West Sumatera, and was given $112 \mathrm{mg}$ per $20 \mathrm{gr}$ body weight orally using the esophageal tube for each mouse. Mice were given seven days adaptation 
using standard food before the treatment started. They were divided randomly into three groups, with every group consists of 10 mice. The first was negative control group without treatment (only aquadest and standard food), the second was positive control group (mice were induced with EPEC), and the third was treatment group (mice were induced with EPEC and given dadih). All groups were given standard food and aquadest daily in ad libitum. Positive control group and treatment group were induced with EPEC contained the population of $108 \mathrm{CFU} / \mathrm{ml}$ as much as $1 \mathrm{ml} /$ day orally, started from day 8 until they have diarrhea. The treatment group was given dadiho rally for 2 weeks, starting from day 8 until day 21, using the esophageal tube (Figure 2.1).

The study was conducted in Pharmacy Laboratory of Andalas University, Biomedical Laboratory and Pathology Anatomy Laboratory of Medical Faculty Andalas University, from June 2016 until May 2017. Diarrhea duration was observed from the frequency of mice defecated every day, and the feces consistency was calculated from feces trace on filter paper at the base of the mice cage. Diarrhea in mice was defined if the frequency is more than 12 times per day and of liquid or soft consistency (diameter of feces $>1 \mathrm{~cm}$ ). The Level of TNF- $\alpha$ and sIgA in mice were determined using feces sample from mice intestine on the final day of the experiment. The examination was completed using ELISA from Elab science.

Data were analyzed by checking the normal distribution using the Kolmogorov-Smirnov test. One way ANOVA was performed on continuous variable and normal distribution of data. Kruskal Wallis test was performed if data distribution was not normal. Statistical significance was tested at $\mathrm{p}<0.05$, and data analysis was continued using post hoc LSD test. The study was reviewed and approved by The Committee of the Research Ethics of the Faculty of Medicine, Andalas University.

\section{Results}

Dadih supplementation on the duration of acute diarrhea(Figure 1) showed that diarrhea in the EPE Cinduced group ( $4.10+/-1.52$ days, mean $+/$ - SD) was significantly different $(\mathrm{p}=0.007)$ from the group without dadih $(8,80+/-4.24$ days). There was no difference in secretory immunoglobulin A (sIgA) level (Figure 2) between groups $(\mathrm{p}=0.142)$. The level in negative control group was $6.22+/-3.73 \mathrm{ng} / \mathrm{ml}$, in positive control group $8.29+/-2.31 \mathrm{ng} / \mathrm{ml}$, and in treatment group $8.69+/-2.43 \mathrm{ng} / \mathrm{ml}$. There was also no difference in TNF- $\alpha$ level (Figure 3 ) between groups $(\mathrm{p}=0.422)$. The level in negative control group was $169.30+/-143.51 \mathrm{ng} / \mathrm{ml}$, in positive control group $238.10+/-116.72 \mathrm{ng} / \mathrm{ml}$, and in treatment group $173.18+/-70.58 \mathrm{ng} / \mathrm{ml}$. 


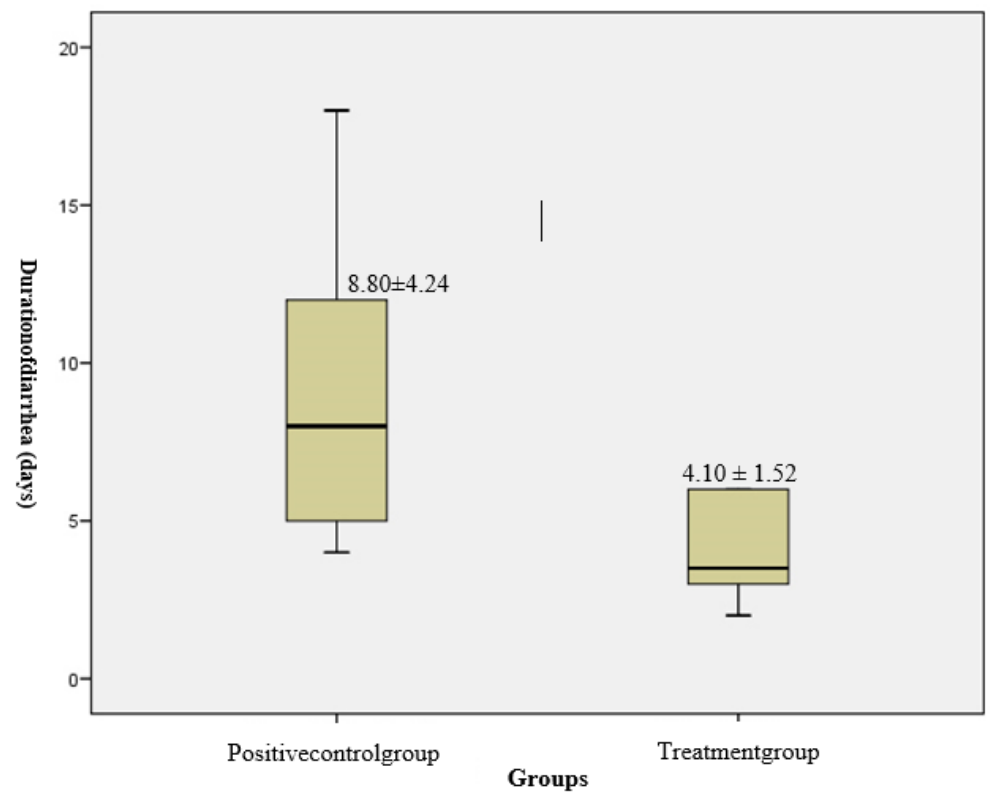

Fig. 1. Durationofacutediarrhea in mice (days)

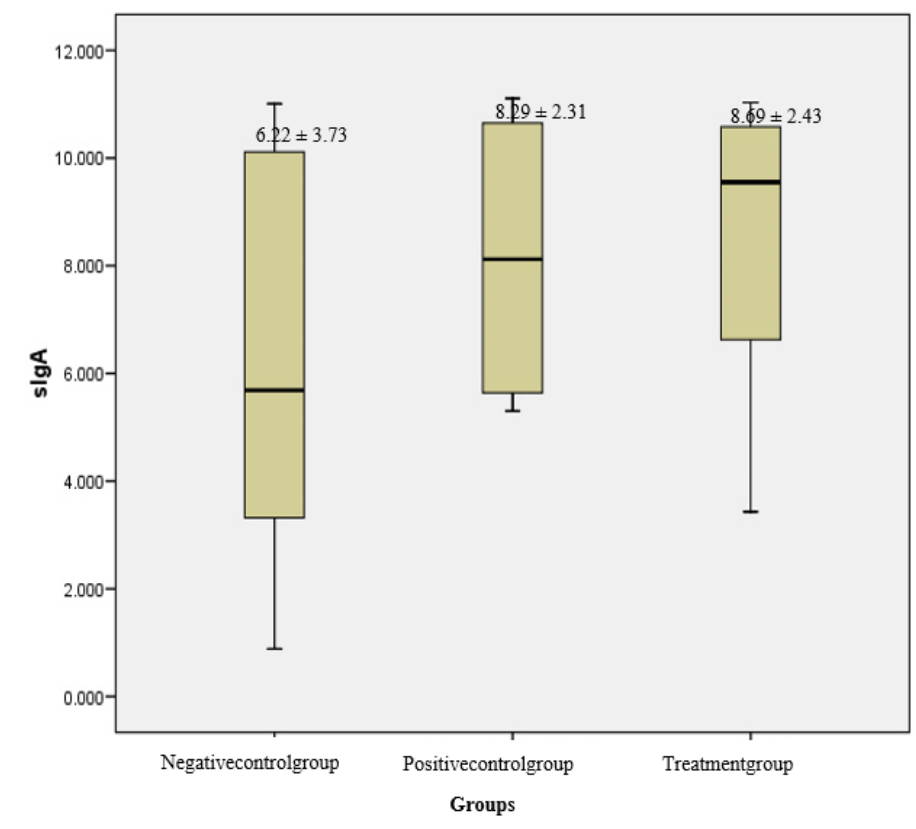

Fig. 2. Levels ofsIgA in mice (ng/ml). 


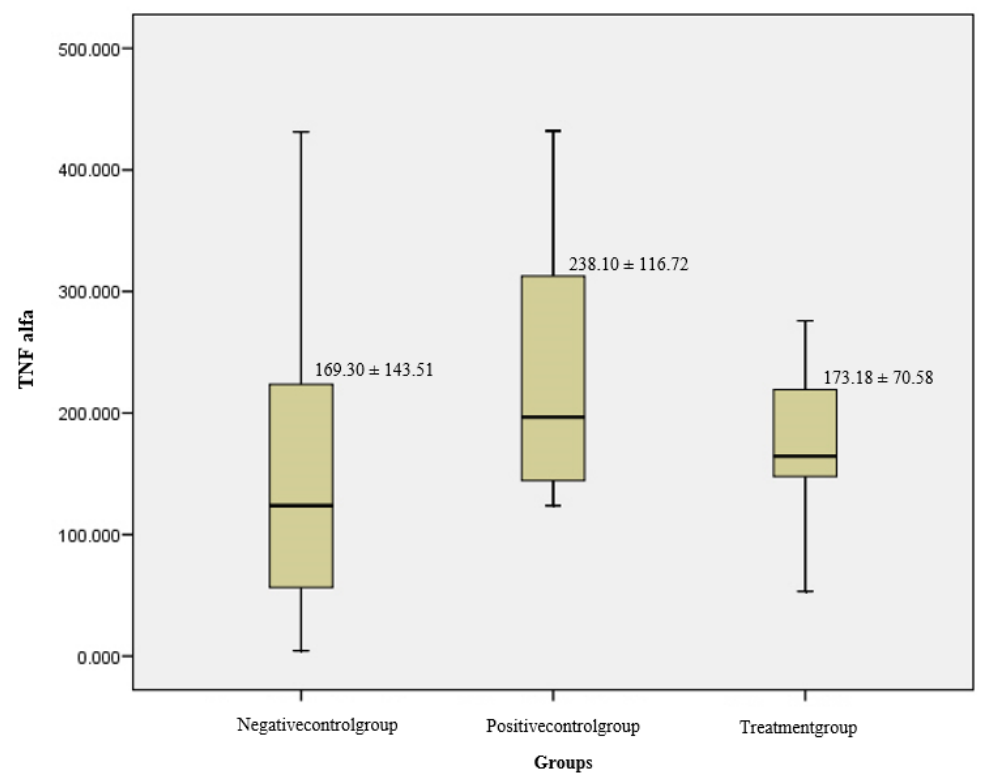

Fig. 3. TNF- $\alpha$ level in mice.

\section{Discussion}

The study showed the group given dadih had shorter diarrhea duration $(4.10 \pm 1.52)$ when compared to positive control group $(8.80 \pm 4.23)$. The result was not much different with Oyetayo in Nigeria, who found that EPEC induced mice will have diarrhea longer than EPEC induced mice given with L. acidophilus[14]. Another study by Shinta, Hatantyo \& Wijayahadi in 84 children with diarrhea in Dr.Kariadi Hospital Semarang showed that mean diarrheal duration was shorter in children given L. reuteri and L. acidophilus-LGG compared to control group[15].Dadih as traditional probiotic consists of various lactic acid bacteria dominated by Lactobacillus strains [10]. Administration of dadih as traditional probiotic was able to stop adhesion of EPEC on intestinal mucosa, increasing microflora balance, protecting intestinal villi, decreasing pro-inflammatory cytokine level and increasing production of sIgA so that diarrhea will stop.[15,16]

This study showed Tumor Necroting Factor- $\alpha$ level was lower in treatment group given dadih $(173.18 \pm 70.58 \mathrm{ng} / \mathrm{ml})$ if compared with a positive control group without given dadih $(238.10 \pm 116.72 \mathrm{ng} / \mathrm{ml})$. However, this difference is not significantly different. The supplemented probiotic can protect the epithelial cell from mucosal destruction by Escherichia coli and protect from mucosal destruction by TNF- $\alpha$. [5] Yuliwati et al. in her research in Padang also reported that there was the decreasing level of TNF- $\alpha$ after administration of Pediococcus isolate dadih with three different dosages [17]. Pena and Versaloviciin Houston also reported that LGG specifically slowed down TNF- $\alpha$ production toward apoptosis or cytotoxic influence[18]. Aslinar et al in Padang also reported that the highest reduction of TNF- $\alpha$ was found in diarrhea mice given with dadihand Weisselaparamesenteroides isolate compared with 
positive control group and negative control group[19]. However, Asemi et al. in Iran reported that there were no significant differences of TNF- $\alpha$ level between pregnant women who were given probiotic (Lactobacillus acidophilus and Bifidobacterium animals) and pregnant women who were not given probiotic[20]. They concluded there was no effect of probiotic administration with reduction of TNF- $\alpha$ level[20]. Gobel et al.also reported there were no significant differences in TNF- $\alpha$ level between children who were given probiotic Ls-33 and children who were not given probiotic Ls-33[21].

Secretory Immunoglobulin A level was higher in the treatment group given dadih $(8.69 \pm$ $2.43 \mathrm{ng} / \mathrm{ml})$ if compared with negative control group $(6.13 \pm 3.87 \mathrm{ng} / \mathrm{ml})$ and positive control group without given dadih $(8.29 \pm 2.31 \mathrm{ng} / \mathrm{ml})$, and this difference was also not significant. Isolauri proposed that administration of lactic acid bacteria orally stimulate the various mucosal immune system, specific and nonspecific, especially increasing sIgA level[22]. It was similar to a study by Putra and Asviandri, where there was a significant increase insIgA level in EPECinduced mice after administration of dadih Pediococcuspentosaceus and Weisellaparamesenteroides isolate as probiotic[16,23]. Putra et al.also showed that effects of supplementation of fermented milk as Acidophilus milk, kefir, or control on IgA level in mice with normal intestine or sensitized with dichlorobenzene allergen did not show a significant difference $(p>0.05)$. [16]

Dadih administration did not affect the reduction of TNF- $\alpha$ level and increasing sIgA level allegedly because there were differences in host response toward probiotic that can be influenced by bacterial strain. This study used pure dadih so that the dominant strain that took a role in intestinal mucosal repair and immunity could not be determined. Fuller argued that the differences of host response toward probiotic were determined by bacterial strain being used, the level of bacterial resistance to animal condition, the age of host, and the environment to store bacteria before being used [24].

\section{Conclusions}

In conclusion, this study showed higher IgA level and lower TNF- $\alpha$ level in the treatment group was not statistically significant.

\section{References}

[1] WHO.:Diarrhoealdisease.Fromhttp://www.who.int/mediacentre/factsheets/fs330/en.[Retrieved Apr 15, 2016] (2013)

[2] Dewi, E.Khairil. Mudatsir. Analisis potensi anti bakteri teh rosella terhadap paparan Enteropathogenic Eschericia coli (EPEC) padamencit (Mus musculus). Jurnal Kedokteran Syiah Kuala, 13(2):77-85 (2013)

[3] Joint Food and Agriculture Organization/World Health Organization Working Group.:In : Guidelines for evaluation of probiotics in food. From http://www.fao.org/es/esn/food/ [Retrieved March 20, 2016] (2002)

[4] Sudarmo SM. Peranan probiotik dan prebiotic dalam upaya pencegahan dan pengobatan diare pada anak. Disampaikan dalam Kongres Nasional II Badan Koordinasi Gastroenterologi Anak Indonesia. Bandung (2003)

[5] Hsu, TR. Chen, SJ.Wu, TC.Chung, RL. Tang, RB.: Tumor necrotizing factoralpha and interleukin 10 in viral and bacterial gastroenteritis in children. J chinmedvassoc, 68(6). pp 250253(2005) 
[6] Surono IS.: Indonesian dadih. In: Puniya AK (ed). Fermented milk and dairy products first edition. CRC Press: 377-99(2015)

[7] Pato, U.: Potensi bakteri asam laktat yang diisolasi dari dadih untuk menurunkan risiko penyaki tkanker. Jurnal Natur Indonesia 5(2): 162-66 (2003)

[8] Ngatirah, A.Harmayanti, ES.Utami, T.: Seleksi bakteri asam laktat sebagai agensi aprobiotik yang berpotensi menurunkan kolesterol. Prosiding Seminar Industri Pangan. PATPI (II): 63-60 (2000)

[9] Hasono A, Wardoyo R, Otani H.: Microbial flora in dadih, a traditional fermented milk in Indonesia. Lebensmittel-Wissenchaft\&Technologie 22: 20-24 (1989)

[10] Sirait, CH.Setiyanto, H.:Evaluasi mutu dadih didaerah produsen. Balai Penelitian Ternak, Ciawi, Bogor. Prosiding Seminar Nasional Sains dan Teknologi Peternakan(1995)

[11] Maheswari, R.: Characteristic of lactic acid bacteria indigenous dadiah as the candidate for probiotics in gastrointestinal condition. Prosiding Seminar Hasil-Hasil Penelitian IPB 2010, pp 56-72. Indonesia (2010)

[12] Liu, J. Wan, R. Xu, XF. Wang, XP. Yang, WJ. Xia, YJ. Liu, H. et al.: Effect of lianshu preparation on lipopolysaccharides-induced diarrhea in rats. World J Gatroenterol 15 (6); 200915 (2009)

[13] Baratawidjaja, KG.: Imunologi Dasar Edisi Ke-11. Jakarta: Badan Penerbit(2014)

[14] Oyetayo, VO.: Performance of rats gastrically dosed with faecal strain of Lactobacillus acidophillus and challenged with Eschericia coli. Afr. J. Biotechnol. 3: 409-11(2004)

[15] Shinta, K. Hatantyo. Wijayahadi, N. Pengaruh probiotik pada diareakut: penelitian dengan 3 preparat probiotik. Sari Pediatri, 13(2): 89-95 (2011)

[16] Putra, BS.:Pengaruh pemberian Pediococcuspentosus isolate dadih terhadap frekuensi buang air besar, kadar secretory immunoglobulin A dan tinggi vili ileum pada mencit diare yang diinduksi Enteropathogenic Eschericia coli [thesis]. Padang : University of Andalas.(2013)

[17] Yuliawati.Jurnalis, YD.Purwati, E.Lubis, G.: The effect of pediococcuspentosaceus on stool frequency, TNF- $\alpha$ level, gutmicroflora balance in diarrhea-induced mice. The Indonesian journal of gastroenterology hepatology and digestive endoscopy, 13(2). 97-102(2012)

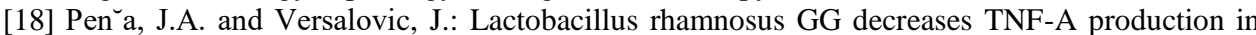
lipopolysacharide-activated murine macrophages by a contact- independent mechanism. Cell. Microbiol. 5, 277-285(2003)

[19] Aslinar.Jurnalis, YD.Purwati, E. Sayoeti, Y.: Probiotic weisellaparamesenteroides on enteropathogenic Escherichia coli-induced diarrhea. Paediatrindones, 54(1): 1-8 (2014)

[20] Asemi, Z. Jazayeri, S. Najafi, M. Samimi, M. Mofid, V. Shidfar, F. Foroushani, AR. et al.: Effects of daily consumption of probiotic yoghurt on inflammatory factors in pregnant women : a randomized controlled trial. Pak.J.Biol.Sci.14(8):476-482 (2011)

[21] Gøbel, RJ. Jensen, SM. Frøkiaer, H. Mølgaard, C. Michaelsen, KF.: Obesity, inflammation and metabolic syndrome in Danish adolescents. ActaPaediatr ;101:192-200 (2012)

[22] Isolauri M.: Probiotics. Best Practice and Research Clinical Gastroenterology, 18 (2): 299-313 (2004)

[23] Asviandri. Pengaruhpemberian Weisselaparamesenteroides isolate dadih terhadap frekuensi buang air besar, kadar secretory immunoglobulin A dan tinggi vili ileum pada mencit diare yang diinduksi Enteropathogenic Eschericia coli [thesis]. Padang : University of Andalas (2013)

[24] Fuller R.: Probiotics: the Sdientific basis. Ed.Fuller R London; Chapman and Hall (1992) 